\title{
The Effect Of The Economic Downturn On The Way People Travel For Leisure And For Business: The Case Of Spain
}

Ramon Diaz-Bernardo, Ph.D., IU University, Madrid, Spain

\begin{abstract}
This study contributed to existing literature by investigating how business and leisure travelers make travel-related decisions. By developing scales to measure travel behavior and travel decision-making criteria, this study contributes to the literature on business travelers vs. leisure travelers. Finally, this study proves a convergence in the behavior of business travelers vs. leisure travelers, in their motivations and decision-making criteria, and provides possible explanations for this trend and avenues for potential future research lines.
\end{abstract}

Keywords: Leisure And Business Travel; Economic Downturn; Travel-Related Decisions; Spain

\section{INTRODUCTION}

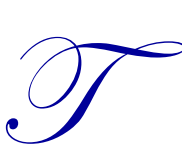

he tourism and hospitality industry tends to differentiate clearly between the behavior of the business traveler and that of the leisure traveler (Yavas and Bakus, 2003; Kashyap and Bojanic, 2000). From hospitality to transportation, the tourism sector has always assumed that the business traveler makes travel-related choices that are fundamentally different from those made by the leisure traveler, especially when it comes to their selection criteria for choosing where to stay (lodging) or how to get there (transportation). Yavas and Bakus (2003) suggest that leisure travelers and business travelers exhibit distinctive attitudes and evaluate product and service characteristics differently based on the purpose of travel.

The tourism industry and academia assume that the purchase motivations of the leisure traveler are very different from those of the business traveler, placing different weights on dimensions of service and price (Yavas and Bakus, 2003). It is assumed, for example, that consumers traveling for business purposes show far less concern about the value they get for the price they pay than do individuals traveling for pleasure, and it is also assumed that business travelers value more the quality of public hotel areas while leisure travelers place more importance on the quality of the room and price (Kim, 2009).

These differences have been reported by Yesawitch (2003) and by Yoo and Lee (2002), who have analyzed the behavior and selection criteria of the business traveler and the leisure traveler when choosing hotels and airlines, respectively.

Yesawitch (2003), using data from the U.S. National Travel Monitor, found that the most influential factors for hotel selection among leisure travelers were ranked as follows: $1^{\text {st }}$ - value for the price; $2^{\text {nd }}-$ location of the hotel, $3^{\text {rd }}$ - room rate; $4^{\text {th }}$ - previous experience with hotel or chain; $5^{\text {th }}$ - reputation of hotel or chain. While the most influential factors for business travelers were: $1^{\text {st }}$ - location of hotel; $2^{\text {nd }}$ - previous experience with hotel chain; $3^{\text {rd }}$. reputation of hotel chain; $4^{\text {th }}$ - value for the price; $5^{\text {th }}$ - room rate.

Yoo and Lee (2002) studied airline choice for international flights and found that the most important attributes for the leisure traveler were: $1^{\text {st }}$ - air fare; $2^{\text {nd }}$ - convenience of flight schedule; $3^{\text {rd }}$ - on time performance; $4^{\text {th }}$ - seat availability. For the business traveler, the ranking was different: $1^{\text {st }}$ - convenience of flight schedule; $2^{\text {nd }}-$ on-time performance; $3^{\text {rd }}$ - frequent flyer program; $4^{\text {th }}$ - air fare. 
Concerning the airline of choice, there also seems to be a divide in the market between the business traveler and the leisure traveler. We tend to assume that low cost airlines are basically for leisure travelers and network carriers are for business travelers. Mason (2001) studied business traveler decision-making in the UK and found that only $32 \%$ of business travelers have a positive attitude towards low cost airlines. Turner (2003) analyzed the profile and airline choice of passengers of a low cost carrier (EasyJet) and a network carrier (British Airways) finding that low cost passengers fly mostly for leisure, are younger, come from a diversity of occupations, do not participate so much in frequent flyer programs, and are less frequent flyers.

\section{TOWARDS A CONVERGENCE OF BUSINESS AND LEISURE TRAVEL BEHAVIOR}

This hypothetical difference in behavior between the business traveler and the leisure traveler might have been true during the generous early 1990s and mid 2000s, when most Western countries were enjoying a buoyant and growing economy with strong corporate profits and large traveling expense accounts that were not subject to very detailed examination. But today the situation has changed radically and now companies and institutions are drastically reducing corporate traveling expenses in a general trend towards cost reduction and improved efficiency both in private companies and public institutions (AMEX Global Business Travel Report 2012).

Our hypothesis is that today things have changed and we face a travel industry where individuals, whether traveling for business or leisure, have become far more price sensitive; value for money is probably becoming the most important thing when traveling.

The concept of value for money is present from the moment a traveler chooses a vacation destination, decides which airline to fly, opts for a hotel to stay at for business purposes or a resort to enjoy a holiday and makes his mind up about where to eat. As a consequence, we hypothesize that in a context of a strong economic crisis the purchase motivations of business travelers and leisure travelers are becoming quite similar and individuals tend more and more to behave in the same way when traveling for business and when traveling for leisure.

The concept of value has become central in marketing literature. In tourism and in any other industry the best performing firms are those that constantly find new ways to deliver products or services with a better perceived value (Parasuraman, 1977). The value of a product or service for a traveler is determined by the extent to which it helps the traveler achieve desired ends as well as the importance of these ends (Kashyap and Bojanic, 2000). Value is the consumer's overall assessment of the utility of a product based on perceptions of what is received and is given (Zeithaml, 1988, p. 14). The buyer's perception of value represents a tradeoff between the qualities and benefits they perceive in the product relative to the perceived sacrifice of paying the price (Monroe 1990, p.46).

This trend towards a convergence in the behavior of business and leisure travelers looking for value is probably also a consequence of traveling costs like airline tickets or hotel rates being much more transparent and easier to compare on the internet.

The trend towards a convergence in the behavior of business and leisure travelers that we are researching in this project should be also understood as stemming from the fact that they are actually the same person. The same individuals travel sometimes for business purposes and sometimes for pleasure, so it is not so strange that their criteria for making travel decisions like choosing an airline or accommodation tend to go in the same direction independently from the reason for the trip.

In a study called "Portrait of Affluent Travelers" (Yesawitch, 2006) we can see how among affluent travelers (those who enjoy an annual household income higher than US\$150,000) hotel preferences remain invariable, whether the primary purpose of the trip is business or pleasure. The top five preferred lodging brands both for business and leisure travel are Hyatt, Ritz-Carlton, Four Seasons, Starwood, and Marriott.

Following this line of convergence between the business traveler and the leisure traveler, we have found that one of the main objectives of all the big players in the travel and hospitality industry is finding a product proposal that is appealing at the same time for the business traveler and the leisure traveler (Adams, 2004). Finding a convergence in the needs and likes of business travelers and leisure travelers would make the market bigger for 
these players. The economic downturn that we are facing in Europe and in the US is affecting the travel-related spending habits of companies and business travelers. Both the frequency of travel and the average spending per business traveler have been reduced in the US and in Europe. According to an American Express study (2012), business trips in the US have dropped by $22 \%$ since 2000 . But in the same study we found that the leisure segment has held up comparatively well. That's why attracting leisure travelers to traditionally business-oriented hotels has become very important to many hotel brands. On this topic, hotel industry executives like David Greydanus, Senior VP for Hilton Hotels Corporation, says that "Every hotel company targets leisure as a segment because the biggest impact has been from the fall-off in business travelers. While many companies have cut travel, the American public is loath to give up its travel opportunities, especially domestic travel. Leisure is not more attractive in terms of profitability, but it's more stable" (Adams, 2004).

\section{RESEARCH DESIGN AND METHODOLOGY}

In this study we have analyzed whether the behavior and decision-making criteria of business and leisure travelers are converging. In order to determine this, we conducted a survey among Spanish business travelers, trying to develop a profile of them when traveling for business purposes and for leisure purposes and analyzing their travel decision-making criteria and the factors affecting their choices of transportation and accommodation.

For this study a quantitative research design was selected using an online Likert scale survey questionnaire to collect data regarding business traveler behavior, and traveling decision-making criteria, as well as profiles and demographic attributes. Multiple choice questions for the demographics were included in the survey. We took a sample of 1,000 business travelers in Spain. The survey was administered initially in March 2013 as a pilot study to establish reliability and validity. Recent studies about the use of internet-based respondent pools indicate a trend towards acceptance of these pools for sampling. Lawton (2005) researched using the internet as a tool to increase accessibility and survey populations, construction of online surveys, and the reliability of their results. These studies conclude that online surveys are acceptable as long as survey constructions followed the same research principles as old-fashioned paper surveys. Further, the addition of a pilot survey step to validate the instrument, and inclusion of a criterion through a two-step self-selection process to complete the survey provided a level of validity on representativeness of the sample population to the selected target population. The e-mail addresses of the potential participants were generated by a Zoomerang respondent pool of over a million individuals.

The pool represented a cross-section of people in all categories of demographics. These individuals selfscreened in or out of the survey by indicating acceptance to complete the survey answering yes to having traveled at least three times on business in the last year. The survey was conducted in April 2013. The sample was segmented according to geography to cover the five first Spanish regions by GDP (Madrid, Cataluña, Valencia, the Basque Country and Balearic Islands).

The questionnaire covered first the demographic questions, and then the questions related to travel behavior and choice criteria when traveling for business or for leisure.

Demographics (multiple choice questions):

1. Gender

2. Age

3. Salary

4. Job position

5. Company size (small, medium, large)

Travel behavior (multiple choice questions)

1. Number, frequency and length of stay of business travel and leisure travel

2. Destination of the trip (national or international) for business travel and leisure travel

3. Mixing business and leisure travel in the same trip. 
Decision-making criteria (Likert scale questions)

1. Who selects the flights and hotels for business travel and leisure travel?

2. What are the criteria for choosing airlines and hotels when traveling for business vs. leisure?

3. The effect of internet consumer-generated content, word of mouth, customer reviews, and travelers' opinions when traveling for business vs. leisure.

\section{RESULTS AND FINDINGS}

Considering the strong downturn in the economic situation of Spain, the market we are using to do this field research, we anticipated a convergence of the behavior, motivations and selection criteria of the business traveler and the leisure traveler and that convergence has been proven by our field research.

Results were segmented and cross-sections were analyzed by the different demographics considered in the sample: age, gender, salary, job position and company size. We found differences in travel behavior by segmenting the sample of business travelers by frequency of travel (Brown, 2004) into frequent travelers (those spending more than 23 nights a year in hotels), moderate travelers (between 6 and 22 nights a year in hotels) and light travelers (between 1 and 5 nights a year in hotels). We also found that the results differed when considering international travelers vs. local travelers, but in both cases we found a clear convergence of business travelers and leisure travelers towards value for money.

Concerning the decision-making criteria, we expected to see an effect based on who was making the traveling decisions, and that was also found in our survey. Concurring with Mason (2003), we observed different decision-making criteria when it was the traveler himself who selected the airline and the hotel, as opposed to the traveler's secretary or a travel department. Moreover, attitudes towards low cost airlines and hotel attributes were found convergent for business and leisure travel.

\section{CONCLUSION}

Overall, this study has contributed to the existing literature by investigating how business travelers and leisure travelers make their travel-related decisions. By developing scales to measure travel behavior and travel decision-making criteria we have contributed to the literature on business travelers vs. leisure travelers. Finally, we have proved our hypothesis related to a convergence in the behavior of business travelers vs. leisure travelers, in their motivations and decision-making criteria, and we have provided possible explanations for this trend and avenues for potential future research lines.

\section{AUTHOR INFORMATION}

Ramon Diaz-Bernardo, Ph.D., is Professor of Marketing, IE Business School, Madrid, IU University, Madrid, Spain. Email: ramon.diaz@ie.edu

\section{REFERENCES}

Adams, B. (2004). Business Brands Target Stronger Leisure Mix. Hotel Management. February, 2004.

American Express Global Business Travel Report 2012, available at: https://businesstravel.americanexpress.com/wp-content/uploads/2012/08/American-Express-GlobalBusiness-Travel-Forecast-2012.pdf

Brown, P. (2004). Better Rewards for Hotel Loyalty. The McKinsey Quarterly. September 2004.

Kashyap, R. and Bojanic, D. (2000). "A Structural Analysis of Value, Quality, and Price Perceptions of Business and Leisure Travelers". Journal of Travel Research. Vol. 39 Aug, pp 45-51.

Kim, Y. (2009). "Business vs. Leisure Travelers: Their Response to Negative Word-of-Mouth". The Journal of American Academy of Business, Cambridge. Vol. 15 No. 1, pp. 70-76.

Lawton, L. (2005). Sampling Bias Concerns in Web Based Research. Tech Society Research, Berkeley, CA. 
Mason, K. J. (2001). “Future Trends in Business Travel Decision Making”. Air Transportation Research Society 2001 Conference, Jeju, South Korea.

Monroe, K. B. (1990). Pricing: Making Profitable Decisions. New York: McGraw-Hill.

Parasuraman, A. (1997). "Reflections on Gaining Competitive Advantage through Customer Value". Journal of the Academy of Marketing Science. Vol. 25 No. 2, pp. 154-161.

Turner, S. (2003). “Comparison of Passenger Profiles and selection Criteria: A Study of London-Amsterdam Passengers". Air Transportation Research Society 2003 Conference, Toulouse, France.

Yavas, U. and Bakus, E. (2003). "What Do Guest Look for in a Hotel? A Multi-Attribute Approach". Services Marketing Quarterly. Vol. 25 No. 2, pp. 1-9.

Yesawitch, P. C. (2003). "Business and Leisure Travelers: Is There Really a Difference?" Hotel Management. November 3, 2003

Yesawitch, P. C. (2006) "Portrait of Affluent Travelers." Hotel Management. November 2006.

Yoo, K. E., and Lee, Y. I. (2002). “Air Passengers' Airline Choice Behavior for International Flight”. Air Transportation Research Society 2002 Conference, Seattle, WA, USA.

Zeithaml, V. A. (1988). "Consumer Perceptions of Price, Quality, and value: A Means-Ends Model and Synthesis of Evidence”. Journal of Marketing. Vol. 52, pp. 2-22. 


\section{NOTES}

